\title{
Nuclear Medicine Methods for Evaluation of Abnormal Parathyroid Glands in Patients with Primary and Secondary Hyperparathyroidism
}

\author{
Albena D. Botushanova ${ }^{1}$, Nikolay P. Botushanov ${ }^{2,3}$, Marianna P. Yaneva ${ }^{4}$ \\ ${ }^{1}$ Department of Clinical Oncology, Section of Radiotherapy and Nuclear Medicine, St George University Hospital, Plovdiv, Bul- \\ garia \\ 2 Second Department of Internal Diseases, Section of Endocrinology, Faculty of Medicine, Medical University of Plovdiv, Plovdiv, \\ Bulgaria \\ ${ }^{3}$ Clinic of Endocrinology, St George University Hospital, Plovdiv, Bulgaria \\ ${ }^{4}$ Complex Oncology Center, Plovdiv, Bulgaria
}

\section{Correspondence:}

Albena D. Botushanova, Department of Clinical Oncology, Section of Radiotherapy and Nuclear Medicine, St George University Hospital, 15A Vassil Aprilov Blvd., 4002, Plovdiv, Bulgaria

E-mail: abotushanova@abv.bg

Tel:+359888277662

Received: 13 Nov 2016

Accepted: 15 May 2017

Published Online: 25 May 2017

Published: 22 Dec 2017

Key words: hyperparathyroidism, scintigraphy, ${ }^{99 \mathrm{~m} T c-s e s t a m i b i,}$ 99mTc-tetrofosmin

Citation: Botushanova AD, Botushanov NP, Yaneva MP. Nuclear medicine methods for evaluation of abnormal parathyroid glands in patients with primary and secondary hyperparathyroidism.

Folia Medica 2017;59(4):396-404. doi: 10.1515/folmed-2017-0054
Considered rare disease in the past, primary hyperparathyroidism (PHPT) has dramatically increased in incidence over the past thirty years with the introduction of routine calcium measurements; it is now approximately 42 per 100000 persons. By far, the most common lesion found in patients with PHPT is the solitary parathyroid adenoma, occurring in $85 \%-90 \%$ of patients, while in the rest $10 \%$ $15 \%$ primary hyperplasia of the parathyroid glands is present. Currently, the most widely used surgical approach is minimally invasive parathyroidectomy which is associated with less post-surgery complications and shorter operation time. To be successful this procedure needs to rely on a precise preoperative localization of the abnormal parathyroid glands, hence preoperative parathyroid imaging gained so large importance. The rationale for locating abnormal parathyroid tissue prior to surgery is that the glands can be notoriously unpredictable in their location. There is a general consensus that the best imaging procedure identifying abnormal parathyroid glands is the preoperative scintigraphy with ${ }^{99 m T c-s e s-~}$ tamibi or ${ }^{99 m}$ Tc-tetrofosmin. It is characterized with high sensitivity and specificity exceeding those of ultrasound, CT or MRI. Combining scintigraphy with the other imaging techniques increases the precision for topic localization.

\section{INTRODUCTION}

Primary hyperparathyroidism (PHPT) is due to excessive production of parathyroid hormone from one or more abnormal parathyroid glands and causes hypercalcemia. Secondary hyperparathyroidism (SHPT) is characterized with increased secretion of PTH, usually much higher than in PHPT, as a result of other concomitant diseases which lead to profound and prolonged hypocalcemia. In SHPT more than one parathyroid gland is affected. Considered rare disease in the past, the incidence of PHPT has changed dramatically during the last thirty years with the introduction of routine calcium measurements and is now considered to be approximately 42 per 100000 persons. Women are affected more frequently than men, in a ratio of approximately $3: 1$. PHPT occurs predominantly in individuals in middle age with a peak incidence between ages 50 and 60 years and can reach 4 cases per 1000 persons in women older than 60 . At the time of diagnosis, most patients with PHPT do not have classic symptoms like osteitis fibrosa cystica, nephrocalcinosis, nephrolithiasis, or signs associated with disease. Symptomatic PHPT is now exception rather than the rule, with more than three-fourths of patients having no symptoms, making detected changes of the blood values of cal- 
cium, phosphorus and parathyroid hormone (PTH) to be the only reason for diagnosis. ${ }^{1}$ By far the most common lesion found in patients with PHPT is the solitary parathyroid adenoma, occurring in $85 \%-90 \%$ of patients, while in the rest $10 \%-15 \%$ primary hyperplasia of the parathyroid glands is present. ${ }^{2}$ In the past the standard surgical approach for PHPT was the bilateral four-gland parathyroid exploration with the removal of each gland which showed changes macroscopically. While in most of the patients with PHPT only one parathyroid gland is affected, the above mentioned surgical approach is inappropriate in all cases. Unilateral approaches are appealing in a disease in which only a single gland is involved. These procedures include a unilateral operation in which the gland on the same side that harbors the adenoma is ascertained to be normal. So nowadays, the currently most widely used surgical approach is the minimally invasive parathyroidectomy which is connected with less postsurgical complications and shortens the time of operation. ${ }^{3}$ The objective is to minimize the length of incisions and the associated increased pain and longer duration of hospital stay. To be successful this procedure needs to rely on a precise preoperative localization of the abnormal parathyroid glands. That's why preoperative parathyroid imaging gained so large importance. The rationale for locating abnormal parathyroid tissue prior to surgery is that the glands can be notoriously unpredictable in their location. There is a general consensus that the best imaging procedure identifying abnormal parathyroid glands is the preoperative scintigraphy with ${ }^{99 \mathrm{~m}} \mathrm{Tc}$ - sestamibi or ${ }^{99 \mathrm{~m}} \mathrm{Tc}$-tetrofosmin. It is characterized with high sensitivity and specificity exceeding those of ultrasound imaging, CT or MRI. Combining scintigraphy with the other imaging techniques increases the precision for topic localization.

\section{ANATOMY OF THE PARATHYROID GLANDS}

Parathyroid glands differ in shape and size. Typically four glands are present and are located adjacent to the dorsal surface of the thyroid lobes - two upper and two lower pairs. Normal glands tend to be flat and oval and normal measurements are $3 \times 5 \times 7 \mathrm{~mm}^{4}$ The combined weight of all parathyroid glans is 90 to $130 \mathrm{mg}$ and the superior glands are smaller than the inferior. ${ }^{5}$ Autopsy series demonstrate that four glands are found in $91 \%$ in subjects, five glands in $4 \%$, and three glands in 5\%. ${ }^{6}$ Approximately 5\% of humans have supernumerary (more than four) parathyroid glands. ${ }^{7}$ Supernumerary glands are most commonly found within the thymus. Although gland distribution may differ widely, the superior parathyroid glands, originating from the fourth pharyngeal pouch, are commonly found along the posterior surface of the upper two-thirds of the thyroid gland (92\%). The inferior parathyroid glands have a more variable distribution than the superior ones. They originate from the third pharyngeal pouch together with the thymus. They migrate caudally until they reach the lower pole of the thyroid gland and $17 \%$ of them touch the inferior border of the thyroid gland, $26 \%$ are within the superior horn of the thymus, and $2 \%$ are in the mediastinal thymus. ${ }^{8}$ The variable anatomic distribution makes the inferior glands more difficult to locate than the superior ones. Histollogically, parathyroid glands are made of chief, oxyphillic and transient oxyphillic cells mixed with fat tissue. Chief cells produce PTH and the oxyphillic cells, which are rich of mitochondria, are with poorly defined function. ${ }^{9}$

\section{EVOLUTION OF THE SCINTIGRAPHY OF THE PARATHYROID GLANDS}

The lack of the perfect imaging method for precise localization of parathyroid adenomas has led to search for an alternative imaging techniques. In the past, one of the most widely used procedure was the ultrasound (US). Because of the great anatomic variations of the parathyroid glands, their small sizes, the presence of more than one abnormal gland and the high frequency of concomitant morphological changes of the thyroid gland, US proved to be specific but with low sensitivity. Later on, other more contemporary and sophisticated methods, like scintigraphy with various nucleotides, computed tomography (CT) and magnetic resonance imaging (MRI) came into consideration. De Feo et al. ${ }^{10}$ compared the sensitivity of CT, MRI, US and ${ }^{99 \mathrm{~m}} \mathrm{Tc}$-sestamibi scintigraphy for proper localization of abnormal parathyroid glands and found to be $13 \%, 17 \%, 27 \%$ and $57 \%$, respectively. They showed that ${ }^{99 \mathrm{~m}} \mathrm{Tc}-$ sestamibi scintigraphy was the most reliable imaging method, especially combined with US (96\%). Historically, the success of scintigraphy had been compromised by the failure of finding pharmaceutical agent with specific topic accumulation in parathyroid glands. Scintigraphy of the parathyroid glands was further complicated by their close localization to the thyroid gland. That's why to find a way to differentiate both glands on obtained images was crucial. This was first achieved by a combined use of two radionucleotides with different uptake in the thyroid and 
parathyroid cells. The latter allowed to perform a subtraction of the obtained images of both glands and to visualize only the abnormal parathyroid glands, but this method proved to be time consuming and with greater radiation exposure to the patients. ${ }^{11}$ The first widely used radionucleotide for detecting hyperfunctioning parathyroid glands during the 80's was ${ }^{201}$ Thallium chloride $\left({ }^{201} \mathrm{Tl}\right) .{ }^{201} \mathrm{Tl}$ chloride accumulates equally in thyroid and parathyroid cells and to make differentiation between both glands possible its application was followed by an injection of ${ }^{99 \mathrm{~m}} \mathrm{Tc}$-pertechnetate, which uptakes only in the thyroid gland. Afterwards, ${ }^{99 \mathrm{~m} T \mathrm{Tc}-\text { pertechnetate }}$ thyroid images were digitally subtracted from the images obtained with ${ }^{201} \mathrm{Tl}$ chloride to allow visualization of the parathyroid glands. ${ }^{12}$

\section{PARATHYROID SCINTIGRAPHY WITH ${ }^{99 \mathrm{M} T C}$ - SESTAMIBI}

Introduced in clinical practice by Coakley et al. in $1989^{13}$, the ${ }^{99 m} \mathrm{Tc}$-sestamibi scintigraphy significantly improved the role of preoperative scintigraphy in patients with hyperparathyroidism. ${ }^{99 \mathrm{~m}} \mathrm{Tc}$-sestamibi consists of lipophilic cationic molecules. After being intravenously injected these molecules distribute throughout the body depending on the local blood supply and through passive diffusion enter into the cells and intracellularly accumulate into the mitochondria. ${ }^{14}$ Visualization of parathyroid adenomas and hyperplastic parathyroid glands depends on the presence of oxyphillic cells, which are rich of mitochondria. Although it was firstly used as a cardiotropic agent, later on it was discovered that this radionucleotide accumulates also in a variety of benign and malignant tumors. Normally ${ }^{99 m} \mathrm{Tc}-$ sestamibi distributes in parotid and submandibular salivary glands, thyroid gland, the heart and the liver. No accumulation in normal parathyroid glands is observed. Studying the mechanisms determining the uptake of ${ }^{99 \mathrm{~m} T c}$-sestamibi in different tissues O'Donety et al. ${ }^{15}$ discovered that it predominantly accumulated in cells rich of mitochondria. The cells of parathyroid adenomas are such cells ${ }^{16}$, while the normal parathyroid cells are not ${ }^{17}$. Apart from the presence of mitochondria, accumulation of ${ }^{99 \mathrm{~m}} \mathrm{Tc}-$ sestamibi into the cells depends also on their metabolic activity, the phases of the cellular cycle, the weight and the size of the tumor. It was established that the highest rates of uptake of ${ }^{99 m} \mathrm{Tc}$-sestamibi is seen in the solitary adenomas of the parathyroid glands. Clarifying the reasons for accumulation of ${ }^{99 \mathrm{~m}} \mathrm{Tc}$-sestamibi in pathologically changed para- thyroid glands, Carpentier et al. ${ }^{18}$ discovered that it depended on the type of cells that build up the adenomas. Not only the amount of intracellular mitochondria was important but also the quantity of oxyphillic cells in the tumors. If the percentage of oxyphillic cells exceeded $25 \%$ accumulation of ${ }^{99 \mathrm{~m} T c-s e s t a m i b i}$ was observed in $78 \%$ of cases. False negative results were possible if the oxyphillic cells did not have sufficient amount of mitochondria. ${ }^{19}$ This new radionucleotide rapidly replaced ${ }^{201} \mathrm{Tl}$ chloride because it showed better quality of the images and higher sensitivity for detecting abnormal parathyroid glands, with less radiation exposure..$^{20}$ Subtraction of thyroid images obtained with ${ }^{123} \mathrm{I}$ or ${ }^{99 \mathrm{~m}}$ T-pertechnetate (both with predominant thyroid accumulation) from images acquired after previous application of ${ }^{99 \mathrm{~m}} \mathrm{Tc}$-sestamibi at one and the same visit represents a variation of this procedure. ${ }^{21}$ ${ }^{99 \mathrm{~m}} \mathrm{Tc}$-sestamibi accumulates also in the thyroid gland, but the washout periods differ, showing faster disappearing from the thyroid gland and a delayed one from parathyroid cells. This allows successful visualization of pathologically changed parathyroid glands on the images obtained later - 1.5-2 h after administration of the radionucleotide. This different retention of the tracer in both glands may be related to some down-regulation of the P-glycoprotein system in parathyroid adenomas slowing down the washout of the nucleotide. ${ }^{22}$ Conversely, in parathyroid hyperplasia, these so called multidrug-related resistance molecules can be upregulated and can cause faster washout of ${ }^{99 \mathrm{~m}} \mathrm{Tc}$-sestamibi and cause false negative results. ${ }^{23,24}$

To avoid this disadvantage and to improve sensitivity and specificity, Tailefer et al. ${ }^{25}$ recommended the use of single-isotope dual phase (early and late) scintigraphy based upon the suggestion that ${ }^{99 \mathrm{~m}} \mathrm{Tc}$-sestamibi is washed out faster from the thyroid gland than from the hyperfunctioning parathyroid cells. This single-isotope dual phase scintigraphy gained popularity due to its convenience. The fact that ${ }^{99 \mathrm{~m}} \mathrm{Tc}$-sestamibi can also be accumulated by solitary thyroid nodules diminishes the specificity of this procedure, especially in areas with higher incidence of nodular goiter. ${ }^{26}$ Some parathyroid adenomas can also show rapid washout of ${ }^{99 \mathrm{~m}} \mathrm{Tc}$-sestamibi and make their visualization difficult during this procedure..$^{27}$ This disadvantage can be avoided by performing a subtractional scintigraphy with consecutive use of a second radionucleotide with preferential accumulation in the thyroid gland. D Casara et al. ${ }^{28}$ 
have used a combination of US examination with dual-isotope scintigraphy with ${ }^{99 \mathrm{~m}} \mathrm{Tc}$-pertechnetate and ${ }^{99 \mathrm{~m}} \mathrm{Tc}$-sestamibi for preoperative localization of parathyroid adenomas. Following such a complex diagnostic approach parathyroid adenomas were visualized in $95.2 \%$ of the cases (20 patients out of 21). Reaching such high diagnostic precision allows minimization of the extent of surgical procedure and gives way to applying routinely and successfully minimally invasive parathyroidectomy of the pathologically changed glands. ${ }^{28}$ Ozkaya et al. ${ }^{29}$ evaluated the diagnostic and preoperative localization capacity of ${ }^{99 \mathrm{~m}} \mathrm{Tc}$-sestamibi scintigraphy and US in patients with PHPT. They concluded that the overall sensitivities of ${ }^{99 m} \mathrm{Tc}$-sestamibi scintigraphy, US and combined techniques were $85.3 \%, 72,5 \%$ and $90.4 \%$, respectively. So the most successful approach seemed to be concurrent application of both modalities. Comparing different imaging methods, Pons et al. ${ }^{30}$ and Ishibashi et al. ${ }^{31}$ pointed out that ${ }^{99 \mathrm{~m}} \mathrm{Tc}$-sestamibi scintigraphy has higher sensitivity and specificity than US and CT in detecting adenomas of the parathyroid glands. With regards to the hyperplasia of the parathyroid glands ${ }^{99 \mathrm{~m}} \mathrm{Tc}$-sestamibi scintigraphy showed to be of less value and the authors concluded that exactly the nature of the pathological cells' changes determined the accumulation of ${ }^{99 \mathrm{~m}} \mathrm{Tc}$-sestamibi.

Hyperplastic parathyroid glands are visualized in $10 \%$ to $62.5 \%$ of the cases according to different authors. ${ }^{32,33}$ In multiple endocrine neoplasia syndrome, where hyperplasia of the parathyroid glands is frequently seen, only $55 \%$ of the abnormal glands are seen on ${ }^{99 \mathrm{~m}} \mathrm{Tc}$-sestamibi scintigraphy. ${ }^{30}$ Kusakabe et al. ${ }^{34}$ compared the results of ${ }^{99 \mathrm{~m} T c-}$ sestamibi scintigraphy and US evaluation in patients with hyperparathyroidism and discovered that the efficacy of these imaging procedures was $100 \%$ and $97 \%$, respectively. ${ }^{99 \mathrm{~m}} \mathrm{Tc}$-sestamibi scintigraphy showed to be highly effective in discovering ectopic hyperfunctioning parathyroid glands, which according to Rothmund et al. ${ }^{35}$ can be observed in $20 \%$ of the cases with PHPT and can represent a diagnostic and therapeutic problem. Rubello et al. ${ }^{36}$ examined 18 patients with PHPT and determined the sensitivity of ${ }^{99 \mathrm{~m}} \mathrm{Tc}$-sestamibi scintigraphy and US for discovering abnormal glands to be $100 \%$ and $83.3 \%$, respectively.

Visualizing small parathyroid adenomas represents a specific problem. D Moka et al. ${ }^{17}$ examined 92 patients with PHPT. Postsurgical evaluation showed that in 39 of the patients the weight of removed adenomas was less than $0.5 \mathrm{~g}$. In these cases, preoperative US evaluation showed no changes, but in $87 \%$ of them ${ }^{99 \mathrm{~m}} \mathrm{Tc}$-sestamibi scintigraphy discovered adenomas and if combined with SPECT technique sensitivity was increased to $95 \%$.

In patients with SHPT ${ }^{99 \mathrm{~m} T c-s e s t a m i b i}$ scintigraphy shows different results. Takebayashi et al. ${ }^{37}$ compared the sensitivity of ${ }^{99 \mathrm{~m}} \mathrm{Tc}$-sestamibi scintigraphy in patients with PHPT and SHPT and the results were $91 \%$ and $83 \%$, respectively. The authors explained this with the observed differences in the sizes and cellular contents (chief:oxyphillic cells ratio). Torregrosa et al..$^{38}$ performed dual-phase single-isotope ${ }^{99 \mathrm{~m}} \mathrm{Tc}$-sestamibi scintigraphy of the parathyroid glands in 27 patients with SHPT. They found a direct relationship between the rate of ${ }^{99 \mathrm{~m}} \mathrm{Tc}$-sestamibi accumulation and the serum levels of parathyroid hormone and the phase of the cells' cycles at the tame of examination. The lowest level of accumulation corresponded to $G(0)$ phase and the highest to - phase $G(2)+S$. No correlation with the weight of the glands was observed. They stated that the fixation of the radionucleotide depended on the functional status of the tissues, i.e. increased accumulation accompanies the active growing phase of the cells. Some authors ${ }^{32}$ highlighted the limited potential of ${ }^{99 \mathrm{~m}} \mathrm{Tc}$-sestamibi scintigraphy, underlying its importance only in clinically manifested disease and in relapses of the hyperparathyroidism. The efficacy of this procedure in PHPT and SHPT was $100 \%$ and $71 \%$, respectively. In subclinical cases of hyperparathyroidism the efficacy of this scintigraphy was low. In parathyroid adenomas the accumulation of the radionucleotide did not depend on their size and weight, while in hyperplastic parathyroid glands such correlation was present.

The reason why not all pathologically changed parathyroid glands accumulate radionucleotide remains unclear. This may be due to the different degree of activity and proliferation of the cells of the parathyroid adenomas. It was suggested that there is a relationship between nucleotide accumulation and the degree of autonomy of the cells of the adenoma, i.e. the loss of the suppressive effect of calcium upon the secretion of the parathyroid hormone. The cells of the parathyroid adenomas and these of the hyperplastic glands show higher suppressive threshold for calcium levels or have no threshold at all in comparison with the normal parathyroid cells. Due to this fact, these cells secrete more PTH for any given calcium level, show higher metabolic rate and capability to accumulate more 
${ }^{99} \mathrm{~m}$ Tc-sestamibi. Hyperplastic parathyroid glands are to some extent with preserved functional connection with normal calcium homeostasis, respond to the normal suppressive stimulus, have lower metabolic rate and accumulate less of the radionucleotide.

Due to its higher affinity to the parathyroid adenomas, ${ }^{99 \mathrm{~m}} \mathrm{Tc}$-sestamibi scintigraphy was used in cases of relapse of the hyperparathyroidism after parathyroidectomy or after autotransplantation of parathyroid glands. Hung et al. ${ }^{39}$ described positive results after using ${ }^{99 \mathrm{~m} T c-s e s t a m i b i}$ scintigraphy for discovering hyperfunctioning parathyroid glands after successful autotransplantation following surgical removal of all hyperplastic parathyroid glands. This method proved to be highly informative and detects ongoing changes of transplanted parathyroid gland much earlier than other imaging procedures such as MRI, CT and US.

Nowadays there are several imaging methods for discovering hyperplastic parathyroid glands. Decreased sensitivity in multigland disease compared with single-gland disease is well recognized for planar and SPECT imaging. The study of Lomonte et al. $^{40}$ aimed to evaluate the value of dual-phase ${ }^{99} \mathrm{~m}$ Tc-sestamibi scintigraphy in preoperative localization of the hyperplastic parathyroid glands in patients with secondary hyperparathyroidism. Their conclusions were that ${ }^{99 \mathrm{~m}} \mathrm{Tc}$-sestamibi scintigraphy did not show high sensitivity in discovering hyperplastic glands, nevertheless it was of help to discriminate between patients with nodular and diffuse hyperplasia. That's why ${ }^{99 \mathrm{~m}} \mathrm{Tc}$-sestamibi scintigraphy has limited value in preoperative evaluation of patients with secondary hyperparathyroidism. Using ${ }^{99 \mathrm{~m} T c-s e s t a m i b i ~ S P E C T / C T ~ d i d n ' t ~ s h o w ~}$ higher sensitivity in multiglandular disease and this was not related to lesion weight or location. ${ }^{41}$ For still unknown reasons, ${ }^{99 \mathrm{~m}} \mathrm{Tc}$-sestamibi scintigraphy shows more sensitivity in discovering pathologic changes of the lower pairs of parathyroid glands than in the upper ones.

The role of ${ }^{99 \mathrm{~m}} \mathrm{Tc}$-sestamibi scintigraphy in patients with end-stage renal disease and secondary hyperparathyroidism is still unclear. Olaizola et al. ${ }^{42}$ evaluated the value of ${ }^{99 \mathrm{~m}} \mathrm{Tc}$-sestamibi scintigraphy in patients with SHPT. They studied how the uptake of ${ }^{99 \mathrm{~m}} \mathrm{Tc}$-sestamibi was suppressed by the use of calcitriol in these patients and what was its correlation with the levels of parathyroid hormone. ${ }^{99 \mathrm{~m}} \mathrm{Tc}$-sestamibi scintigraphy managed to visualize 1 or more (maximum 3) parathyroid glands in most but not in all patients on chro- niodialysis with PHT levels above $600 \mathrm{pg} / \mathrm{ml}$. Performing suppressive test with calcitriol $(2 \mathrm{mg}$ of calcitriol applied i.v. after each chroniodialysis for two consecutive weeks) showed suppression of ${ }^{99 \mathrm{~m}} \mathrm{Tc}$-sestamibi uptake at least in one parathyroid gland in $57 \%$ of the cases and full suppression of all glands in $36 \%$. The basal serum level of PHT or its lowering after this test showed to have no predictive value for the suppression of the uptake of ${ }^{99 \mathrm{~m}} \mathrm{Tc}$-sestamibi in the parathyroid glands. They stated that because of its lower sensitivity, the ${ }^{99 \mathrm{~m}} \mathrm{Tc}$-sestamibi scintigraphy is of limited value in preoperative evaluation in uremic patients with secondary hyperparathyroidism, but its significance grows up in localizing still hyperfunctioning glands left after the first operation.

\section{PARATHYROID SCINTIGRAPHY WITH ${ }^{99 \mathrm{M}}$ TC - TETROFOSMIN}

${ }^{99 m}$ Tc-tetrofosmin, another myocardial perfusion agent, was also used for visualizing parathyroid glands in scintigraphy, but the data for its use so far are limited. ${ }^{99 \mathrm{~m}} \mathrm{Tc}$-tetrofosmin shows some similarities with ${ }^{99 \mathrm{~m}} \mathrm{Tc}$-sestamibi although the way of accumulation is different and it is retained mainly in the cytosol than in the mitochondria of the target cells. When used for parathyroid scintigraphy ${ }^{99 m} \mathrm{Tc}$-tetrofosmin shows slower washout from the thyroid gland, which makes it unsuitable for singleisotope dual-phase scintigraphy. ${ }^{43}$ Nevertheless, its sensitivity increases when used in the substractional protocol with SPECT.

Hiromatsu et al. ${ }^{44}$ aimed to confirm the clinical significance of ${ }^{99 \mathrm{~m}} \mathrm{Tc}$-tetrofosmin scintigraphy for topic localization of the hyperfunctioning parathyroid glands in patients with PHPT. They concluded that this method was useful for the clinical practice and that the accumulation of ${ }^{99} \mathrm{~m} \mathrm{Tc}$-tetrofosmin depended on the weight of the tumor and the level of PTH. Vallejos et al. ${ }^{45}$ also studied the diagnostic value of ${ }^{99 \mathrm{~m}} \mathrm{Tc}$-tetrofosmin parathyroid scintigraphy in patients with PHPT. They stated that ${ }^{99 \mathrm{~m}} \mathrm{Tc}$-tetrofosmin was suitable for preoperative localization of abnormal parathyroid glands and that the early images obtained on the 15 th minute were better than those on the 120th minute. ${ }^{99 \mathrm{~m}} \mathrm{Tc}$-tetrofosmin was washed out more slowly from the thyroid gland than ${ }^{99 \mathrm{~m}} \mathrm{Tc}$-sestamibi but both radionucleotides gave better results in comparison with pertechnetate Tl-201 substractional technique. Gallowitsch et al. ${ }^{46}$ pointed out that ${ }^{99} \mathrm{~m} \mathrm{Tc}$-tetrofosmin looked promising alternative of 
${ }^{99 \mathrm{~m}} \mathrm{Tc}$-sestamibi with similar properties and capabilities of discovering parathyroid adenomas. Images obtained by SPECT showed clear advantages and better sensitivity in comparison with planar scintigraphy. SPECT should be used in cases with poor or no accumulation of the isotope when using single-isotope dual-phase protocol. In the areas with endemic goiter US should be performed to avoid misinterpretation of the results because of prolonged retention of the tracer in thyroid adenomas. Dual-isotope substractional scintigraphy with ${ }^{99 \mathrm{~m}} \mathrm{Tc}$-tetrofosmin $/{ }^{99 \mathrm{~m}} \mathrm{Tc}$-pertechnetate and SPECT are highly sensitive methods for localization of parathyroid adenomas and their combination can further improve the diagnostic precision

Garcheva et al. ${ }^{47}$ studied the diagnostic value of combined substractional planar scintigraphy with ${ }^{99 \mathrm{~m}} \mathrm{Tc}$-pertechnetate $/{ }^{99 \mathrm{~m}} \mathrm{Tc}$-tetrofosmin $(37 \mathrm{MBq}$ and $740 \mathrm{MBq}$ ) with SPECT/CT. They concluded that substractional method was useful in patients after thyroid surgery when there were remnants of thyroid tissue and when there were more than one pathologically changed parathyroid gland. Mluchkov $\mathrm{N}$ et al. ${ }^{48}$ performed ${ }^{99 \mathrm{~m}} \mathrm{Tc}-$-sestamibi scintigraphy in patients with clinically and laboratory data for hyperparathyroidism and they concluded that visualization of the hyperfunctoning parathyroid glands correlated with the blood levels of the PHT and was less likely with levels less than 3 times above the upper range (less than $180 \mathrm{pg} / \mathrm{ml}$ ). Kovatcheva $\mathrm{R}$ et al. $^{49}$ comparing the diagnostic value of US with color Doppler and ${ }^{99 \mathrm{~m}} \mathrm{Tc}$-sestamibi scintigraphy for localization of abnormal parathyroid glands in patients with PHPT and SHPT concluded that both methods were highly informative and easy to perform.

\section{PROTOCOLS FOR NUCLEAR MEDICINE EXAMINATION OF PARATHYROID GLANDS}

Generally, three protocols are used: single-phase dual-isotope subtraction, dual-phase single-isotope and combination of both. In single-phase dualisotope procedure one isotope $\left({ }^{99 \mathrm{~m}} \mathrm{Tc}\right.$-sestamibi) is used for visualization of abnormal parathyroid glands and another ( ${ }^{123} \mathrm{I}$ or ${ }^{99 \mathrm{~m}} \mathrm{Tc}$-pertechnetate) for imaging only the thyroid gland. The latter images are digitally subtracted from the first ones and if there is still a residual radionucleotide accumulation seen on the subtracted images, a hyperfunctioning parathyroid gland can be suspected. Disadvantages of this method are the use of two radionucleotides, the necessity of full collaboration from the patient to remain calm and motionless during the examination and the need of very precise positioning of the patient. In addition, there is an increased possibility for the presence of artefacts on the subtracted images. Single-isotope protocol is based on the different washout of the nucleotide from the thyroid and parathyroid glands. In this method, after a single injection of radionucleotide early images on 10-15 min and late images at $1.5-3$ hours are obtained. There are very few studies directly comparing the results from single-isotope dual-phase method with single-phase dual-isotope subtractional technique and the results are conflicting. So far there is no clear confirmed advantages of one method over another. Over the past decades in nuclear medicine were introduced several new methods and devices like SPECT, SPECT/CT gamma cameras, 4D CT and PET/CT. Tomographic images (SPECT) and hybrid ones (SPECT/CT) allow visualization of smaller structures and determination of the precise anatomic localization of the abnormal parathyroid glands. Comparison of 4D CT, US and ${ }^{99 \mathrm{~m}} \mathrm{Tc}-$ sestamibi SPECT/CT in localizing single-gland primary hyperparathyroidism showed that $4 \mathrm{D} C \mathrm{CT}$ outperformed the other two methods in terms of sensitivity $(\mathrm{P}=0.27)$ and specifity $(\mathrm{P}=0.01)$ and provided specific anatomic information and proved helpful in localizing target parathyroid glands of PHPT that were missed by traditional imaging. ${ }^{50}$ There are insufficient data for using PET/CT in parathyroid imaging. PET with ${ }^{18} \mathrm{~F}$-fluorodeoxyglucose $\left({ }^{18} \mathrm{~F}-\mathrm{FDG}\right)$ was used with varying success. One study showed that ${ }^{18} \mathrm{~F}$-FDG PET was more sensitive but less specific than ${ }^{99 \mathrm{~m} T c-s e s t a m i b i}$ SPECT. Other authors reported very low sensitivity for detecting abnormal parathyroid glands. Using PET with ${ }^{11} \mathrm{C}$-methionine in parathyroid examination has been studied in some patients but because of the very short half-life of ${ }^{11} \mathrm{C}$-methionine, only $20 \mathrm{~min}$, its use is limited only to nuclear medicine centers located near to a cyclotron

\section{CONCLUSIONS}

There is general consensus that the best imaging procedure for localization of the abnormal parathyroid glands so far is the scintigraphy with ${ }^{99 \mathrm{~m}} \mathrm{Tc}$-sestamibi or ${ }^{99 \mathrm{~m}} \mathrm{Tc}$-tetrofosmin. With all its advantages and disadvantages it is characterized with sensitivity and specificity exceeding those of ultrasound, CT, MRI or even PET/CT. Combining scintigraphy with the other imaging techniques increases the precision for topic localization but 
it still remains the best single method to visualize hyperfunctionig parathyroid glands. Multidisciplinary approach including nuclear medicine specialists, radiologists, endocrinologists and experienced surgeons is needed to achieve proper treatment of patients with PHPT and SHPT.

\section{REFERENCES}

1. Kearns AE, Thompson GB. Medical and surgical management of hyperparathyroidism. Mayo Clin Proc 2002;77(1):87-91.

2. Ruda JM, Hollenbeak C, Stack BC Jr. A systematic review of the diagnosis and treatment of primary hyperparathyroidism from 1995 to 2003. Otolaryngol Head Neck Surg 2005;132(3):359-72.

3. Russell CF, Laird JD, Ferguson WR. Scan-directed unilateral cervical exploration for parathyroid adenoma: a legitimate approach? World Surg 1990;14(3);406-9.

4. Harnsberger HR, Osborn AG, Ross J, et al. Thyroid gland and parathyroid glands. In: Harnsberger HR, Osborn AG, Macdonald A, Ross J, eds. Diagnostic and surgical imaging anatomy: brain, head and neck, spine. Salt Lake City, Utah: Amirsys; 2006.

5. Dufour DR, Wilkerson SY. Factors related to parathyroid weight in normal persons. Arch Pathol Lab Med 1983;107(4):167-72.

6. Alveryd A. Parathyroid glands in thyroid surgery. I. Anatomy of parathyroid glands. II. Postoperative hypoparathyroidism - identification and autotransplantation of parathyroid glands. Acta Chir Scand 1968;389:1-120.

7. Wang C, Mahaffey JE, Axelrod L, et al. Hyperfunctioning supernumerary parathyroid glands. Surg Gynecol Obstet 1979;148:711-4.

8. Akerstrom G, Malmaeus J, Bergstrom R. Surgical anatomy of human parathyroid glands. Surgery 1984;95:14-21.

9. DeLellis RA. Surgical pathology of the parathyroid glands. In: Randolph G, ed. Surgery of the thyroid and parathyroid glands. St. Louis, Mo: Elsevier; 2003;571-7.

10. De Feo MI, Colagrande S, Biagini C, et al. Parathyroid glands: combination of $(99 \mathrm{~m})$ Tc MIBI scintigraphy and US for demonstration of parathyroid glands and nodules. Radiology 2000;241(2):393-402.

11. Waldorf JC, van Heerden JA, Gorman CA, et al. $(75 \mathrm{Se})$ Selenomethionine scanning for parathyroid localization should be abandoned. Mayo Clin Proc 1984;59:534-7.

12.Ferlin G, Borsato N, Camerani M, et al. New perspectives in localizing enlarged parathyroids by technetium - thallium subtraction scan. J Nuc Med 1983;24(5):438-41.
13. Coakley AJ, Kettle AG, Wells CP, et al. 99mTcsestamibi - a new agent for parathyroid imaging. Nucl Med Commun 1989;10(11):791-4.

14. Arbab As, Koizumi K, Toyama K, et al. Uptake of technetium-99m-tetrofosmin, technetium-99mMIBI and thallium-201 in tumor cell lines. J Nuc Med 1996;37(10):1551-6.

15. O'Donety MJ, Kettle AG, Wells CP, et al. Parathyroid imaging with technetium-99m-sestamibi: preoperative localization and tissue uptake studies. J Nucl Med 1998;33:313-8.

16. Lee VS, Spritzer CE, Coleman RE, et al. The complementary roles of fast spin-echo MR imaging and double-phase $99 \mathrm{~m}$ Tc-sestamibi scintigraphy for localization of hyperfunctioning parathyroid glands. Am J Roentgenol 1996;167(6):1555-62.

17. Moka D, Voth E, Dietlein T, et al. Technetium 99mMIBI-SPECT: a highly sensitive diagnostic tool for localization of parathyroid adenomas. Surgery 2000;128(1):29-35.

18. Carpentier A, Jeannotte S, Verreault J, et al. Preoperative localization of parathyroid lesions in hyperparathyroidism: relationship between technetium - 99 $\mathrm{m}$ - MIBI uptake and oxyphill cell content. J Nucl Med 1998;39(8):1441-4.

19. Benard F, Lefebre B, Beuvon F, et al. Rapid washout of technetium - 99- MIBI from a large parathyroid adenoma. J Nucl Med 1995;36(2):241-3.

20. Bergenfelz A, Tennvall J, Valdermarsson S, et al. Sestamibi versus thallium subtraction scintigraphy in parathyroid localization: a prospective comparative study in patients with predominantly mild primary hyperparathyroidism. Surgery 1997;121(6):601-5.

21. Casas AT, Burke GJ, Sathyanarayana S, et al. Prospective comparison of technetium-99m-sestamibi/ iodine-123 radionuclide scan versus high-resolution ultrasonography for the preoperative localization of abnormal parathyroid glands in patients with previously unoperated primary hyperparathyroidism. Am J Surg 1993;166(4):369-73.

22. Bhatnagar A, Vezza PR, Bryan JA, et al. Technetium-99m-sestamibi parathyroid scintigraphy: effect of P-glycoprotein, histology and tumor size on detectability. J Nuc Med 1998;39:1617-20.

23. Chudzinski W, Niderla J, Lasiecka Z, et al. P-glycoprotein expression influences the result of $99 \mathrm{mTc}$ MIBI scintigraphy in tertiary hyperparathyroidism. Int J Mol Med 2005;16:215-9.

24. Grzela T, Chudzinski W, Lazarczyk M, et al. Persisted/recurrent hyperparathyroidism associated with development of multi-drug resistance phenotype and proliferation of parathyroid transplants. Int $\mathrm{J}$ Mol Med 2004;14:559-99.

25. Taillefer R, Boucher Y, Potvin C, et al. Detection and localization of parathyroid adenomas in patients 
with hyperparathyroidism using a single radionuclide imaging procedure with technetium-99msestamibi (double-phase study). J Nucl Med 1992;33(10):1801-7.

26. Casara D, Rubello D, Piotto A, et al. 99mTc-MIBI radio-guided minimally invasive parathyroid surgery planned on the basis of a preoperative combined 99mTc-pertechnetate/99mTc-MiBi and ultrasound imaging protocol. Eur J Nucl Med 2000;27:1300-4.

27. Benard F, Lefebvre B, Beuvon F, et al. Rapid washout of technetium-99m-MIBI from a large parathyroid adenoma. J Nucl Med 1995;36:241-3.

28. Casara D, Rubello D, Piotto D, et al. 99mTcMIBI radio-guided minimally invasive parathyroid surgery planned on the basis of a preoperative combined 99mTc-pertechnetate/99mTc-MIBI and ultrasound imaging protocol. Eur J Nucl Med 2000;27(9):1300-4.

29. Ozkaya M, Elboga E, Sahin E, et al. Evaluation of conventional imaging techniques on preoperative localization in primary hyperparathyroidism. Bosn J Basic Med Sci 2015;15(1):61-6.

30.Pons F, Torregrosa JV, Vidal-Sicart S, et al. Preoperative parathyroid gland localization with 99Tcsestamibi in secondary hyperparathyroidism. Eur J Nuc Med 1997;24(12):1494-8.

31. Ishibashi M, Nishida H, Okuda S, et al. Localization of parathyroid glands in hemodialysis patients using Tc-99m Sestamibi imaging. Nephrol 1998;78:48.

32. Walgenbach S, Dutkowski P, Andreas J, et al. [99mTc-MIBI-scintigraphy before parathyroid surgery?]. Zentralbl Ihir 2000;124(3):214-9 [German].

33. Mimura Y, Kanauchi H, Ogawa T, et al. Review of 41 patients operated on for primary hyperparathyroidism. Biomed Pharmacother 2000;54(Suppl. 1):72-6.

34. Kusakabe K, Oshima M, Takami H, et al. [Evaluation of clinical utility of $99 \mathrm{mTc}$-MIBI scintigraphy in the localization of hyperfunctioning parathyroid lesions in patients with hyperparathyroidism--a report of multicenter phase III clinical trials]. Kaku Igaku. 1998;35(9):887-99 [Japanese].

35. Rothmund H, Diethelm J, Brunner C, et al. Diagnosis and surgical treatment of mediastinal parathyroid tumors. Ann Surg 1976;183(2):139-45.

36. Rubello D, Mazzarollo R, Casara D. The role of technetium-99m methoxyisobutylisonitrile scintigraphy in the planning of therapy and follow-up of patients with differentiated thyroid carcinoma after surgery. Eur J Nucl Med 2000;27(4):431-40.

37. Takebayashi S, Hidai H, Chiba T, et al. Hyperfunctional parathyroid glands with 99mTc-MIBI scan: semiquantitative analysis correlated with histologic findings. J Nucl Med 1999;40(11):1792-7.

38. Torregrosa JV, Fernandez-Cruz L, Canalejo A, et al. $99 \mathrm{mTc}$-sestamibi scintigraphy and cell cycle in parathyroid glands of secondary hyperparathyroidism. World J Surg 2000;24(11):1386-90.

39. Hung GU, Wu HS, Tsai SC, et al. Recurrent hyperfunctioning in parathyroid gland demonstrated on radionuclide imaging and an intraoperative gamma probe. Clin Nucl Med 2000;25(5):348-50.

40. Lomonte C, Buonvino N, Selvaggiolo M, et al. Sestamibi scintigraphy, topography, and histopathology of parathyroid glands in secondary hyperparathyroidism. Am J Kidney Dis 2006;48(4):638-44.

41. Nichols KJ, Tronco GG, Palestro CJ. Influence of multigland parathyroid disease on $99 \mathrm{~m}$ Tc-sestamibi SPECT/CT. Clin Nucl Med 2016;431(4):282-8.

42. Olaizola I, Zingrafe J, Heuguerot C, et al. [ $\left.{ }^{99 \mathrm{~m}} \mathrm{Tc}\right]-$ Sestamibi parathyroid scintigraphy in chronic haemodialysis patients: static and dynamic explorations. Nephrology Dialysis Transplantation 2000;15(8):1201-6.

43. Fröberg AC, Valkema R, Bonjer HJ, et al. 99mTctetrofosmin or $99 \mathrm{mTc}$-sestamibi for double-phase parathyroid scintigraphy? Eur J Nucl Med Mol Imaging 2003;30:193-6.

44. Hiromatsu Y, Ishibashi M, Nishida H, et al. Technetium-99m tetrofosmin parathyroid imaging in patients with primary hyperparathyroidism. Intern Med 2000;39(2):101-6.

45. Vallejos V, Martin-Comin J, Gonzalez MT, et al. The usefulness of Tc-99m tetrofosmin scintigraphy in the diagnosis and localization of hyperfunctioning parathyroid glands. Lin Nucl Med 1999;24(12):959-64.

46. Gallowitsch HJ, Mikosch P, Kresnik E, et al. Technetium A99m tetrofosmin parathyroid imaging. Results with double-phase study and SPECT in primary and secondary hyperparathyroidism. Invest Radiol 1997;32(8)459-65.

47. Garcheva M, Kostadinova M, Stoynova I, et al. [Comprehensive diagnostics of primary hyperparathyroidism using subtraction planar scintigraphy and SPECT.] Rengenologia y radiologia 2009;48(Suppl. 09):40 [Bulgarian].

48. Mluchkov N, Palashev Y. [99m-TC-MIBI scintigraphy in patients with clinical and laboratory evidence of hyperparthyroidism.] Rengenologia y radiologia 2003;Suppl. 03:76 [Bulgarian].

49. Kovacheva R, Radeva M, Kirilov G, et al. [Diagnostic value of high frequency colour Dopler sonography and 99m-TC-MIBI scintigraphy in primary and secondary hyperparathyroidism.] Rengenologia y radiologia 2004;3:188 [Bulgarian].

50.Suh YJ, Choi JY, Kim SJ, et al. Comparison of 4D CT, ultrasonography, and 99mTc sestamibi SPECT/CT in localizing single gland primary hyperparathyroidism. Otolaryngol Head Neck Surg 2015;152(3):438-43. 


\title{
Методы нуклеарной медицины при оценке аномальных паращито- видных желез у пациентов с первичным и вторичным гиперпара- тиреозом
}

\author{
Албена Д. Ботушанова ${ }^{1}$, Николай П. Ботушанов ${ }^{2,3}$, Мариана П. Янева ${ }^{4}$ \\ ${ }^{1}$ Кафедра клинической онкологии, Секция радиотерапии и нуклеарной медицины, Университетская больница „Св. \\ Георги", Пловдив, Болгария \\ 2 Вторая кафедра внутренних болезней, Секция эндокринологии, Факультет медицины, Медицинский университет - \\ Пловдив, Пловдив, Болгария \\ ${ }^{3}$ Клиника эндокринологии, Университетская больница „Св. Георги”, Пловдив, Болгария \\ ${ }^{4}$ Комплексный онкологический центр, Пловдив, Болгария
}

Адрес для корреспонденции: Албена Д. Ботушанова, Кафедра клинической онкологии, Секция радиотерапии и нуклеарной медицины, Университетская больница "Св. Георги", бул. „Васил Априлов“" № 15А, 4002, Пловдив, Болгария

E-mail:abotushanova@abv.bg Тел:+359888277662

Дата получения: 13 ноября 2016

Дата приемки: 15 мая 2017 Дата онлайн публикации: 25 мая 2017

Дата публикации: 22 декабря 2017

Ключевые слова: гиперпаратиреоз, сцинтиграфия, $99 \mathrm{mT}$ -

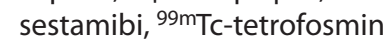

\section{Образец цитирования:}

Botushanova AD, Botushanov NP, Yaneva MP. Nuclear medicine methods for evaluation of abnormal parathyroid glands in patients with primary and secondary hyperparathyroidism.

Folia Medica 2017;59(4):396-404. doi: 10.1515/folmed-2017-0054
Считавшееся редким заболеванием в прошлом, частота проявления первичного гиперпаратиреоза (ПГПТ) резко повысилась за последние тридцать лет после введения рутинного определения кальция и в наши дни считается, что она составляет 42 случая на 100000 населения. До последнего времени наиболее часто встречающимся поражением у пациентов с ПГПТ являлась единичная паратиреоаденома, возникающая у 85-90\% пациентов, а в остальных 10-15 \% случаев наличествует первичная гиперплазия паращитовидных желез. В наши дни наиболее распространённым хирургическим методом является минимально-инвазивная паратиреоидэктомия, ввиду минимальных послеоперационных осложнений и сокращения длительности операции. Для успешного проведения данной процедуры необходима тщательная предоперационная локализация аномальных паращитовидных желез и ввиду этого предоперационная паратиреоидная образная диагностика приобрела такое большое значение. Основной причиной для тщательной локализации аномальной паратиреоидной ткани перед операцией является обстоятельство, что расположение желез может быть действительно непредсказуемым. Сложилось общее мнение, что наилучшей техникой образного исследования для определения аномальных паратиреоидных желез является предоперационная сцинтиграфия с использованием ${ }^{99 \mathrm{mT}}$ - sestamibi или ${ }^{99 \mathrm{mT}}$ Tc-tetrofosmin. Она отличается высокой степенью чувствительности и специфичностью, превышающих аналогичные показатели ультразвуковой диагностики, КТ и ЯМР. Совместное применение сцинтографии с другими методами образных исследований увеличивает точность локализации. 